\title{
Memorialised and Imagined. Meanings of the Urban Space of Vyborg
}

Karhu Jani магистр истории, аспирант, Университет Восточной Финляндии (Йоэнсуу, Финляндия)

\section{Introduction}

How do we see and reflect history? We each have our own memories, thoughts and experiences. Our sense of history is constructed from multiple sources, and a part of that sense is also constructed collectively. The memories of some events and phenomena collectively are so strong that they begin to determine how people see and understand history ${ }^{1}$. It is said that these memories can crystallise in certain places; these places can turn into a refuge for those memories, thus becoming places of memory ${ }^{2}$. This happened in the town of Vyborg.

In this article, I analyse both the urban space of Vyborg in relation to the Finnish tradition of memorialising the town, and the meanings given to certain places. My findings suggest that a certain tradition of memorialising can produce imagined and, in many ways, fixed collective views of history, which is materialising through the popular monuments of the town space. My analysis is concentrating to three central monuments inside the city space of Vyborg: the Castle, the Round Tower and the Library.

This article has its roots in our project "Meanings of an Urban Space, Past and Present". The project is a part of the common research programme "Human Mind", funded by the Academy of Finland and the Russian Academy of Sciences. The Russian partner in the project is St. Petersburg State University. 
My part of the project was to study the meanings of Vyborg's multi-layered city space. Empirical data was collected through surveys ${ }^{3}$ conducted together with the Russian partner, Professor Ludmila K. Ryabova. The aim was to collect comparable material from Finland and Russia ${ }^{4}$. Both the paper and the electronic versions of the questionnaires were created and the data was collected during 2015. The main research question was 'How does the history of the city reflect the meanings given to its buildings and places?', and the main results of our study are presented in our project publication Meanings of an Urban Space. Understanding the historical layers of Vyborg ${ }^{5}$.

The theoretical frame of this study is grounded in the tradition of urban sociological studies of the late $20^{\text {th }}$ century ${ }^{6}$. In this tradition, cities are seen as special fields of human activity, and experiences with personal interpretations have a major role in understanding urban space ${ }^{7}$. This thinking arises from the challenge of studying and understanding towns and cities as both social and physical environments that exist separately and inseparably ${ }^{8}$. In the case of this study, the theoretical starting point is founded on that precise question of how the social (postmemory) and physical (place) meet in the given meanings and memories of city space of Vyborg.

In order to access the theoretical dimensions of my data and make interpretations, I have used the concept of City as an imagined environment. As James Donald puts it, an imagined city embraces not just the cities created by the architects, planners and builders, sociologists, poets and politicians, but also the translation of the places they have made into the imaginary reality of our mental life ${ }^{9}$.

I am using the concept imagined city as a theoretical tool for interpreting the meanings given to places and buildings. This approach can work especially well for $\mathrm{Vy}$ borg, because most of the Finnish discourse concerning the town is based on memories and imaginations going back to the town's 'Golden Age' - its last Finnish years (the 1930s) - and the bitter feelings of loss ${ }^{10}$. My findings suggest that the Finnish tradition and the way of memorialising Vyborg and lost Karelia ${ }^{11}$ have made the imagined city at least equal to the actual city of Vyborg and, in many cases, the meanings of the imagined city are even crucial in contrast to the city today.

Two other theoretical tools related to memory are necessary here. Studying memories and collective memory gives a possibility to examine how lived environments and places are described and made meaningful ${ }^{12}$. The meanings given to the places are combined with memories. Some places become more important than others. Pierre Nora identified the concept of 'places of memory' in his study Realms of Memory (1984-1992). In his conceptualisation, Nora left some room for different kinds of interpretations, from which place of memory is often explained as a physical or non-physical symbol that has become a part of a community's historical memory. In this study, I recognise this definition when using the concept in order to try to understand the memories and meanings connected to some of Vyborg's places and buildings ${ }^{13}$.

The third important concept is 'postmemory'. Marianne Hirsch uses it to describe the relationship that the 'generation after' has to the personal, collective and cultural trauma of the previous generation; a relationship to experiences that they only 'remember' by means of the stories, images, and behaviours with which they grew up. Nonetheless, these experiences were transmitted to the next generation so deeply and effectively that they seem to constitute personal memories in their own right ${ }^{14}$. 
Postmemory, originally used to analyse how Jews handled the memory of the Holocaust, can be useful here, because, losing parts of Karelia after the war created a tradition of memorialising the lost areas in Finland. For the 420,000 Finnish Karelians ${ }^{15}$ evacuated after WWII from the territories ceded to the Soviet Union, losing their homes and lands was a bitter subject for decades. This event can be interpreted as a personal and collective trauma as Hirsch understands it $^{16}$.

The aim is not to test these theoretical aspects but to apply the concepts as an analytic tool from the empirical point of view. This kind of conceptualisation helps to understand how people experience the historical layers of the city and how the meanings of the places are constructed.

\section{Town as a place of memory}

Vyborg is a small provincial town near St. Petersburg. The confirmed history of Vyborg goes back to the $13^{\text {th }}$ century when the Swedes founded Vyborg Castle. After that, Vyborg has had many different functions. First, it was a Swedish fortress and border town, then becoming a Russian border town. In 1812, it became part of autonomous Finland and, finally, in 1917 it rapidly developed into a trade and cultural centre of eastern - and now independent — Finland ${ }^{17}$.

By the end of World War II, the Soviet Union had occupied Vyborg twice; first after the Winter War in March 1940 and later in June 1944. Since World War II, Vyborg has been a part of Soviet Union / Russia. As a result of the war, the whole Finnish population of Vyborg and parts of the surrounding territory of Finnish Karelia was evacuated and resettled elsewhere in Finland. When the Finnish-Russian border finally re-opened at the beginning of the 1990s, the former Finnish Karelians and Vyborgers were able to visit their old homes and places. Even though Vyborg has not been a part of Finland for over 70 years, few cities provoke such feelings among Finns as Vyborg does ${ }^{18}$.

Losing the town in the war has given it a special status in Finnish history telling, in the tradition of memorialising the lost Karelia ${ }^{19}$, and in the media ${ }^{20}$. For the Finns, the places and buildings of the town take shape thorough old photographs, memories, and present day tourism. However, several buildings and places have seen the change of rulers and citizens through the centuries. How does this affect the stories told by the people connected to these places? What are the meanings given to them? Which places are held above others and which are less noteworthy?

The survey for Finns had 107 respondents; $52 \%$ were women and $48 \%$ men. Approximately half of the respondents were aged between 51 and $70,30 \%$ were over 70 years old and $20 \%$ were under 50 years old. Some respondents had actually lived in Finnish Vyborg: $15 \%$ of the respondents were born in the town and $17 \%$ had lived there at some point in their life. Most respondents had visited the town; only $6 \%$ had not. Thus, Vyborg was quite familiar to the people who answered the questionnaire ${ }^{21}$.

The single most important question in the survey was this: "Name three to five (3-5) places or buildings that are meaningful to you and briefly state why and/or what memories or matters they bring to mind."

The answers give a very clear picture of how people see the city. The urban space of Vyborg is divided between collectively and individually recognised places of memory. 
The collective places are widely known historical places and monuments, such as the Castle and the Round Tower, and the individual places are old family homes, workplaces and so forth. The difference here is that whereas different individual family places were mentioned dozens of times, over $80 \%$ of the respondents mentioned these generally known historical places. It is important to understand that these places are not just interesting town attractions. The relationship to these places is often quite personal. Many of them have a huge general and personal symbolic value. The reason why it is possible to name these places as places of memory already at this point is that almost without exception the meanings given to these places somehow relate to the Finnish history of the town ${ }^{22}$.

The five most frequently mentioned important places are:

1. Vyborg Castle.

2. The Round Tower.

3. The Central City Alvar Aalto Library.

4. Monrepos Park.

5. The Market Hall.

In my analysis, I concentrate on the first three places - the Castle, the Round Tower and the Library - and on how the meanings given to these places are connected to postmemory. On average, these three places were clearly the most significant considering the answers on the questionnaire and they cover the history from the beginning of Vyborg until the end of the Finnish 1930s.

In Finnish history writing, the architecture and the objects of urban art are often seen as political and cultural symbols ${ }^{23}$. Vyborg Castle is in its own category when it comes to symbolic values and meanings. In the answers given in the survey, the symbolic value of the Castle is related to Finnishness, Karelia, Finnish independence and protection from the East ${ }^{24}$. The Finnish flag on the top of the tower was mentioned several times. These two objects, the Castle and the flag, seem to be the key to understanding the symbolic meanings given to the place.

Vyborg Castle was founded in 1293. In the meanings given to the Castle, however, 700 years of rich history is somehow compressed into the short period of 26 years when the town belonged to independent Finland. Images of the Castle with the Finnish flag flying on the top of the tower are well known and somehow the Castle has become the most important symbol of the outcome of the war. As one respondent answered: "When visiting Vyborg, my mother said: 'Ooh, if the flag just could still be there'. Our companions agreed."

Here are another three typical notions about the Castle ${ }^{25}$ :

- "A long-standing symbol of the lost Karelia. Deep sorrow."

- "The Castle is a symbol of the Finnish character and freedom."

_ "Passing by the Castle during the evacuation of 1944."

In many cases, the Castle was an indication of the long history of the town, but the very foundation of the actual meaning was leaning towards the symbolic idea of Finnishness and how the castle has been seen as a Finnish 'lock' against the Eastern enemy ${ }^{26}$.

It seems that people see the Castle in a different way from seeing some other interesting sights when abroad. Of course, the Castle is the most recognisable building 
in the town, but seeing the Castle in the famous old pictures with the Finnish flag on top of the tower or the Finnish soldier standing at the front of the castle has greatly affected the way people relate the place to a certain history ${ }^{27}$. According to the data, it seems that this kind of imagined and memorialised history replaces the actual history of the place with nationalistically-biased historical thinking.

Overall, the answers contained 48 mentions of symbolic meanings and memories regarding the Castle. It is notable that there were only a few answers in which the long history of the building was clearly the foundation of the meanings. In contrast, however, several answers arose from stories about 'Finnishness' and the tradition of memorialising the lost Karelia.

The Castle is fixed in the Finnish mental image in a certain way and the survey data affirms this. The references concerning the post-war period are almost absent in the data and, when they do appear, the viewpoint is again that of the Finnish history of the Castle or fantasised mediaeval events. After WWII, the Castle has had two different kinds of histories: the local Russian history ${ }^{28}$ and - in many ways fixed - history within the Finnish tradition. The Castle has become some kind of a fixed town symbol of Finnishness.

The Round Tower was originally a bastion of the old town wall, built in the middle of the $16^{\text {th }}$ century. The meanings given to the place in the survey answers usually have nothing to do with the previous history of the building. During the 1920s and 1930s, the Tower was a restaurant. The restaurant of the Finnish period and the Russian restaurant of today are the main sources of the memories and meanings given to the place. The old Finnish restaurant was very popular and the respondents often recounted how their relatives used to go there: ${ }^{29}$

— "Grandfather partied with his friends and business partners [there]."

- "Round Tower, great parties."

- "The Round Tower is the most important. On the market square next to it, my grandfather sold farm products. We visited the restaurant with my cousins to reminisce with their mother, who worked there."

The Round Tower is present in a popular Finnish pop song ${ }^{30}$ from the 1960s, in which Vyborg and the Tower are mentioned places where you could dance all night and everybody would be happy. This song has had its own effect on the meanings given to the place. Some answers even have direct quotes from the lyrics. Compared with the Castle as the second mediaeval or early modern building presented in the survey, the symbolic value of the Tower is not as important. However, the meanings originating in family history and Finnish Vyborg traditions are more important in this case. As it is with the Castle, the earlier history of the Tower is almost absent in the answers ${ }^{31}$. It also is important to note that in documentaries and pictures the Castle often contains nationalistic and militaristic features, whereas the Round Tower has lively market and restaurant features. This difference is also notable in the survey data.

The viewpoints regarding the meanings given to the Tower vary between family history, personal experiences of visiting the Tower, the Finnish tradition of memorialising, and the history of the building. The tradition of memorialising is constructed collectively but through a continual personal, collective and societal dialogue. This means that memorialising is not necessarily rising form personal experiences, but from collectively 
shared sources ${ }^{32}$. Like one informant implied: "It makes me long for Old Vyborg"33. Old Vyborg is obviously Finnish Vyborg, but the point is that a person longing for that "Old Vyborg" is so young that she has neither lived in nor visited Finnish Vyborg. She is longing for a place that has been passed on to her through stories, images and documentaries. This is a perfect example of how postmemory affects certain places. The meaning of the place is not in its present existence but in the way it is connected to the imagined Finnish Vyborg.

Switching from the mediaeval buildings straight to the functionalism of the 1930s, the Central City Alvar Aalto Library has become one of the most important places in Vyborg in the Finnish imagination. This place is interpreted in the opposite way to the two previously presented places. While the origin of the Castle, or especially of the Round Tower, has rather little to do with the meanings given to them, origin is the keyword to the meanings given to the Library ${ }^{34}$.

The Library was opened in 1935 and was designed by the famous Finnish architect Alvar Aalto ${ }^{35}$. For a long time after WWII, the building was in bad condition. In co-operation with the Finns, the Russians renovated it to as close to the original state as possible. The renovation was completed in $2013^{36}$. Many of the respondents expressed happiness because of the successful renovation. The building has the same use today as it had at the end of the 1930s. In the meanings given to the Library, similar phenomena as with the Castle arise. The Library is not important as an actual library, or to the locals. It is important because of Finnish history, the Finnish architect and - in some cases - the events related to the building during the war ${ }^{37}$. In the answers, the time after the war has two periods: when the building was in a shamefully bad condition and the present situation after it was finally renovated. Here are four typical examples:

- "I visited there for the first time in February 2014. I was happy to see it renovated"

- "It was a great experience to visit there, magnificent Finnish architecture, world famous, things that happened there 20 June 1944 are touching for me."

- "Of course this building is familiar to me. It was in a poor condition, now it is worth a show around."

— "This building is important to my own personal history, designed by Alvar Aalto. I haven't had a chance to see it inside. It is great that they renovated it."

It is worth noticing that this building was only about eight years under Finnish rule. However, for Finns it is valued as one of the most important places and buildings in Vyborg. It is reasonable to assume that the fame of Aalto is the main reason why exactly this library has become such an important image of Finnish Vyborg. It is mentioned so often in the data. When the Library was built, it was also criticised as it was considered unsuitable to be the image of the old town centre ${ }^{38}$.

The citizens of Vyborg today are quite well aware of the Finnish history of the building. However, they do not value it because of the famous designer but because of its functional purpose ${ }^{39}$. It is reasonable to ask if the purpose of the renovation was to cherish the memory of Finnish architecture, and how the locals understand this point of view $^{40}$. It is clear that Finnish people are not connected with the building via its daily use but thorough symbolic and memorialised attributes. Thus, the whole field of meanings given to the building is constructed by the narratives of postmemory. 


\section{Memorialised and imagined town space}

It seems clear that there are buildings and places that are held above others in the city of Vyborg. All of these places also can be considered the main sights of the town. It is important to understand that the significance of these sights arises out of different mentalities. For Russians, the Castle and the Round Tower are interesting mediaeval sights and important figures for the town space exactly from that point of view ${ }^{41}$. For Finns the perspective is quite different. The old history of the sites is somewhere in the background, not totally forgotten, but overrun by the meanings related to Finnish and personal history and especially by the Finnish tradition of memorialising the city.

The whole concept can be summarised in one quotation from the answers to question nine:

"The Castle, the Round Tower, Monrepos Park, Torkkeli Park, Salakka Bay. These are the places mentioned in my grandparents' songs and stories, and it is impossible to explain their meanings. These are the places fixed in the collective memory. They are more than just sights: they are feelings, longing and atmosphere. A world that doesn't exist, even though it does."

The constructed and imagined Vyborg exists in the memories and stories of certain places. It lives in all those stories, often presented via images and cherished memories. According to the survey, it is not the present day town that motivates people to visit. It is the imagined town of the 1920 s and 1930 s, which was lost in the war ${ }^{42}$. The urban historian Dolores Hayden sees the natural features of urban landscape, buildings included, as a storehouse of these memories ${ }^{43}$ and continues that places trigger memories for insiders, who have shared a common past, and at the same time places often can represent shared pasts to outsiders who might be interested in knowing about knowing them in the present ${ }^{44}$.

However, it is not whichever building or place that reaches the special status. Certain monuments inside that urban space can work as a rhetoric tool for collective memory. Monuments like castle are repeating the story of achievements and the struggle of the nation. Even though the story itself could be somewhat imagined. For these kind of places of memory, the values they present must be considered worth of preserving ${ }^{45}$. In the case of Vyborg, these, especially symbolic, values are quite recognizable.

Pierre Nora describes places of memory as some kinds of refuges for collective memory because we do not have the real environments ${ }^{46}$ of memory anymore ${ }^{47}$. These tainted environments of memory are replaced by variously constructed places of memory. Fragmented memories and knowledge are connected to important places and, in these places, memorialising materialises as monuments ${ }^{48}$. In Vyborg, this seems to have happened to several places and buildings. Important monuments like the Castle and the Round Tower have a crucial role in collective memory and the understanding of Vyborg. On the other hand, also regular homes and houses, without any monumental features, have an important role in the tradition of memorialising. The difference between these two rises from the value of the places for each individual's memory and collective memory.

What is the connection between the places of memory and the tradition of memorialising, i.e. postmemory? 
In the stories passed on to the next generations, Vyborg and other lost places were usually presented as wonderful or special ${ }^{49}$.

When the Finnish-Russian border was opened after the collapse of the Soviet Union, Finns wanted to visit their old homes again. Descriptions of the first trips show how strong the feelings were. For those who did not have memories of their own, these trips were a step into the stories they had been told by their parents or grandparents. The places that only had been imagined constructions for decades were seen and felt again. Trips to Vyborg and former Finnish Karelia were like pilgrimages to the past. The reality of the present day was a disappointment to those who had lived in their memories ${ }^{50}$.

All this can be seen in the survey material. The story of lost Vyborg and Karelia has been transferred to the next generations and they carry it on in turn, creating and projecting the original story in combination with their own values and memories. Through the concept of postmemory, the Castle is the long-standing symbol of Karelia, and the Round Tower is the place for happy parties.

That imagined Finnish town is what many respondents said they are seeking in present day Vyborg. They visit the old family places and public places and imagine their relatives living there before the war. This is one example of how the appropriation of space is linked to mental life. In Vyborg, the link between the imagined city and mental life is very strong. As Donald has suggested, it is imagination that produces reality as it exists. Therefore, it is possible to claim that in Vyborg the reality as it exists is quite different for the locals than it is for those Finns who search for their own imagined city ${ }^{51}$.

That image of Finnish Vyborg is over-flowingly romanticised. The main content of the postmemory of Vyborg is the loss of the great city. In the stories, images, film footages and postcards, that flourishing city and its happy and active people are making their way into the historical understanding of the Finnish people. Memorialising started soon after the war and gained momentum after the collapse of the Soviet Union. Especially the last ten years have been beneficial for the literature concerning Vyborg ${ }^{52}$.

Finnish Vyborg literature is full of strong emotional expressions. Vyborg. Lost, but not forgotten is the title of a history book about local sports ${ }^{53}$. Vyborg, the wounded beauty is the title of another history book ${ }^{54}$ and there are many more examples like these. The process has been self-constructing, making the image stronger every time it is repeated by individuals and collectively. The famous photographs of Eino Partanen from the 1930s are perhaps the most used ones, appearing time after time in books, magazines, documentaries, and on the internet ${ }^{55}$. Those iconic pictures present a noble and modern city, producing some kind of a foundation for understanding and imagining the city afterwards.

Another phenomenon is the way the city was lost in the war in the summer of 1944. The debate about responsibilities and reasons started quite early after the war and it is continuing today ${ }^{56}$. The idea of the retreating soldiers leaving the city behind has not been easy to accept ${ }^{57}$.

The third phenomenon that has had a strong influence on the way Vyborg and Karelia have been memorialised are various societies and unions. For example, the Finnish Literature Society of Vyborg has continued operating, located today in Helsinki. Starting in the $1970 s^{58}$, the Society has its own publication series with regular Vyborg-related studies and literature. The newspaper Karjala, originally the main newspaper in Vyborg, 
is still active as a daily paper for evacuated Karelians. The main idea of the paper today is to conserve the heritage of ceded Karelia by writing about its history and about the lives and activities of all those who identify themselves as 'Karelian' in present-day Finland ${ }^{59}$. Besides these old Vyborg-origin actors, almost every municipality from the lost areas has its own municipality society to keep the heritage of their original regions alive ${ }^{60}$.

Moreover, the biggest tabloid in Finland has recently published two special issues connected to Vyborg ${ }^{61}$. There was also a writing contest in these publications. The idea of the contest was to collect memories regarding Vyborg and Karelia. Vyborg also has entered the digital world. A project at the Tampere University of Applied Sciences has constructed a comprehensive website called Virtual Vyborg ${ }^{62}$, and the Finnish Literature Society of Vyborg has developed a digital Vyborg portal ${ }^{63}$.

This shows that Vyborg is not forgotten. On the contrary, it is actively memorialised, studied, and reconstructed. These, and many other examples, are just fragments of the bigger story. Vyborg has become more than the town itself.

The way Vyborg is still considered Finnish — "Ours" - is rising from the situation in which the important example and symbol of the institutionalization of Finnish territory, independence and nationalism ${ }^{64}$ is irreparably lost. These claims of ownership of the town space of Vyborg are resonating from ideas of a holistic Finnishness in these places of memory. This reflects contradictory ways of understanding the town space if compared to the holistic understanding of history presented by the Russian Vyborgers of today ${ }^{65}$.

Writer and researcher Anna Kortelainen wraps up this phenomenon as feelings of loss, yearning and the pain of remembering. The postmemory of Vyborg is full of golden memories. Like Kortelainen describes, despite a contradictory and diverse reality, untarnished memories are constructed by wealth and they choir in unison at heavily laden dinner tables ${ }^{66}$. However, alternative realities, such as poverty or political problems, are excluded from the presented memories, as they do not fit the narrative of the wonderful lost town. The sad parts of the story are losing the town to the Soviet Union and its present day situation and condition. Some historians are trying to give a wider and more realistic image ${ }^{67}$, but the mainstream postmemory has been just as Kortelainen describes.

Anna Maria Åström suggests, using the thinking of Boyer, that the collective memory quite rarely gains the form of complete written history because of its implication with changing present ${ }^{68}$. However, in the case of Vyborg, this is controversial. As I have shown, the postmemory, written or spoken, does not follow this argument.

To go further, Tiina-Riitta Lappi suggests that people are continuously constructing the history of the town by telling stories. At the same time, the town of memories is constantly in the process of changing through new interpretations and memorialising. In the case of Vyborg, however, it seems that the imagined town is not changing. It is represented in related memory time after time, but the main idea has remained fixed to an image of the town as it was before the war. The happy Vyborg in the songs of the 1950s and 1960s is still the same in the meanings given to the town in $2015^{69}$.

This form of postmemory is clearly dominant in the historical understanding of Vyborg and the way of interpreting its history ${ }^{70}$. In collective and personal memory, it is always a matter of what is remembered and how and, on the other hand, what is forgot$\operatorname{ten}^{71}$. Most of all, which interpretations gain the dominant role for the community in this 
case $^{72}$. It is quite possible that the postmemory regarding Vyborg will change. Up until today, the generations of former Vyborgers and their children have had the dominant role in producing the collective memory. They know their Vyborg. Recent studies suggest that in the future the situation might be something else. In a recent study of a group of Finnish teenagers, only a few recognised Vyborg Castle and, most importantly, it was meaningless to them ${ }^{73}$.

\section{Conclusion}

All this implies that certain historical events can create a strong tradition of memorialising, which in turn creates imagined controversial realities for certain places and for the town space. These realities also include strong claims of ownership towards the town space. In many cases, the idea of a holistic Finnishness has overrun the actual and controversial history of the places.

Monuments like Vyborg Castle, the Round Tower, and the Central City Alvar Aalto Library are the core places of memory for Finns. In many cases, however, they are not important because of their present reality but due to their meanings inside the imagination. Typically, this means that buildings and places with rich historical layers mainly provide an exciting and beautiful stage for meanings and memories, in which the town is flourishing, children are playing, markets are full of people and the Finnish flag is on the top of the tower, even though it was only there for about 20 years.

1 Cf. http://www.postmemory.net/; Katajala K., Semi J. Meanings of an Urban Space, Past and Present // Meanings of an Urban Space. Understanding the historical layers of Vyborg / Katajala (ed.). Zürich, 2016. P. 14.

2 Nora P. Realms of memory. Rethinking the French past. Vol. 1. New York, 1996, P. xvii.

3 Using memories, surveys and interviews as sources in research is always problematic. Memories can be mistaken or they can be affected by something the respondent has learned afterwards. People might avoid mentioning some issues or only tell part of the story. On the use of memory, survey and interviews cf. Alastalo M. Metodisuhdanteiden mahti: lomaketutkimus suomalaisessa sosiologiassa 1947-2000. Tampere, 2005; Tuomi J., Sarajärvi A. Laadullinen tutkimus ja sisällönanalyysi. Jyväskylä, 2004.

4 For the Finnish part of the survey, people and groups that already had some kind of connection to or interest in Vyborg were targeted.

5 Editor Kimmo Katajala, published by Lit verlag 2016.

6 The detailed description of the setting of our study is presented in our project publication.

7 Cf. Muistin kaupunki. Tulkintoja kaupungista muistin ja muistamisen paikkana / Lento K., Olsson P. (eds.). Helsinki, 2013; Memories of my town. Identities of Town Dwellers and Their Places in Three Finnish Towns / Åström Anna-Maria, Korkiakangas Pirjo \& Olsson Pia (eds.). Helsinki, 2004; Donald J. Imagining the Modern City. London, 1999; Massey D. Space, Place and Gender. Minneapolis, 1994; Harvey D. Social justice and the city. Baltimore, 1973. From the viewpoint of recent approaches towards urban space, memories are seen important in affecting how people react to and use urban space. Muistin kaupunki. Tulkintoja kaupungista muistin ja muistamisen paikkana / Lento K., Olsson P. (eds.). Helsinki, 2013. P. 9. Memorising the city becomes crucial concerning the urban space of Vyborg. Urban space can also be interpreted as a representation of cultural convention and meanings. Cf. Kervanto-Nevanlinna A. Näköaloja kadunkulmalta. Kaupunkihistorian kirjoituksia. Helsinki, 2005. P.99. 
8 City or urban space can be a state of mind, physical, mental, changing and stable. Cf. Donald J. Imagining the Modern City. London, 1999. P. 7-8.

9 Donald J. Imagining the Modern City. P. 8. With this kind of interpretation, the city we experience is simultaneously the actual physical place but also a city in the pictures, TV-documentaries or in the memories from childhood.

10 Nevalainen P. Karjala takaisin — palautuskeskustelun vaiheet sotavuosista 2000-luvulle // Viipurin läänin historia IV. Karjala itärajan varjossa / Yrjö Kaukiainen \& Jouko Nurmiainen (eds.). Porvoo, 2010. P. 493-501.

11 Trauma of losing the city and intensive tradition of memorising created a mythical past to Vyborg. Cf. Viipurin historian kirjoitus: politiikkaa, teemoja ja aukollisuuksia. Muuttuvien tulkintojen Viipuri / Koskivirta, Paavolainen \& Supponen (eds.). Helsinki, 2016. P. 10.

12 Muistin kaupunki. Tulkintoja kaupungista muistin ja muistamisen paikkana / Lento K., Olsson P. (eds.). Helsinki, 2013. P. 12.

13 Nora described this broader concept of "lieu de memoire" this way: “...is any significant entity, whether material or non-material in nature, which by dint of human will or work of time has become a symbolic element of the memorial heritage of any community": Nora P. Realms of memory. Rethinking the French past. P.xvii.

14 Marianne Hirsch website: http://www.postmemory.net/

15 Ethnic Finns formed the vast majority of the population of the ceded parts of Karelia, though representatives of the ethnic Karelian group were also represented, collectively referred to as 'Karelians'.

16 Cf. Karhu J. Meanings of the urban space of Vyborg for Finns // Meanings of an Urban Space. Understanding the historical layers of Vyborg / Kimmo Katajala (ed.). Zürich, 2016.

17 Katajala K., Semi J. Meanings of an Urban Space, Past and Present. P. 12.

18 Ibid. P.11; It is argued that the former citizens of Vyborg felt that they have lost more than their homes and houses. Memoirs show that many of them felt like losing an entire way of life. Cf. Koskivirta A., Paavolainen P., Supponen S. Viipurin historian kirjoitus: politiikkaa, teemoja ja aukollisuuksia in Muuttuvien tulkintojen Viipuri / Koskivirta, Paavolainen \& Supponen (eds.). Helsinki, 2016. P. 10.

19 For Finns, the territories ceded to the Soviet Union as a result of WWII formed part of Finnish Karelia, including the Karelian Isthmus. Karelia in this context does not refer to the present-day Russian Republic of Karelia, which is referred to as 'Eastern Karelia'.

20 Art historian Anna Kortelainen names Vyborg as a "city of longing”. Cf. http://areena.yle. fi/1-3119050. 25.2.2016.

21 Karhu J. Meanings of the urban space of Vyborg for Finns. P. 278.

22 Ibid.

${ }^{23}$ Kervanto-Nevanlinna A. Rakennettu kaupunki muistin ja merkitysten kiinnekohtana / Lento K., Olsson P. (eds.). Helsinki, 2013. P. 273.

${ }_{24}$ This idea of symbolic values goes back to the 1930s. Cf. Kirby D. A Concise History of Finland. Cambridge, 2006. P. 15.

25 Translations in this and similar situations are done by the author.

${ }_{26}$ Turtola $M$. Viipuri ja sen linnoitukset puolustuksen symboleina / Koskivirta, Paavolainen \& Supponen (eds.). Helsinki, 2016.

27 Pictures about the castle and flag were quite popular, for example the moment when the flag was again in its place after the Finns recaptured the city in 1941. Also the soldier standing at the front of the castle photographed by Eino Partanen is iconic among Finnish media.

${ }_{28}$ Petrov E., Krinitsyna T. From a Finnish urban space to Soviet urban planning: the Development, Approval and Implementation of the first Soviet master plan of Vyborg in 1944-1953 // Meanings of an Urban Space. Understanding the historical layers of Vyborg. P. 123-149; Shikalov Y. Russian, Lost, Fairy-tale: Images of Vyborg from the 1940s to the 2010s // Meanings of an Urban Space. Understanding the historical layers of Vyborg. P. 223-249.

${ }^{29}$ Karhu J. Meanings of the urban space of Vyborg for Finns. P. 281-282.

30 Sellanen ol Viipuri, Melody by Ralph Benatzky, Finn. lyrics by E. Kettunen — Saukki. Juha Vainio recorded the song 1965. 
${ }^{31}$ Karhu J. Meanings of the urban space of Vyborg for Finns. P. 281-282.

${ }_{32}$ Muistin kaupunki. Tulkintoja kaupungista muistin ja muistamisen paikkana / Lento K., Olsson P. (eds.). P. 18-19.

${ }^{33}$ Survey data.

${ }^{34}$ Karhu J. Meanings of the urban space of Vyborg for Finns. P.282.

${ }_{35}$ About Aalto Cf. http://www.alvaraalto.fi/. 14.4.2016.

${ }^{36}$ It is suggested that the importance of the renovation arose from the evaluation of the library as one of the most important works from the early years of Alvar Aalto. Cf. Kervanto-Nevanlinna A. Rakennettu kaupunki muistin ja merkitysten kiinnekohtana, 2013, 281.

37 The renovation project raised notable nationalistic conversation in Finland. Ibid.

38 Interviews.

${ }^{39}$ Ryabova L. Meanings of the urban space of Vyborg for Russians // Meanings of an Urban Space. Understanding the historical layers of Vyborg. P. 272.

${ }^{40}$ Kervanto-Nevanlinna A. Rakennettu kaupunki muistin ja merkitysten kiinnekohtana. P. 282 .

${ }^{41}$ Cf. Ryabova L. Meanings of the urban space of Vyborg for Russians.

${ }_{42}$ Karhu J. Meanings of the urban space of Vyborg for Finns.

${ }^{43}$ Hayden D. The Power of Place. London, 1995. P. 9.

${ }_{44}$ Ibid. P. 46.

${ }^{45}$ Compare to Nora P. Realms of memory. Rethinking the French past. P. 6-8.

${ }^{46}$ Where the memory is a real part of the everyday experience.

${ }_{47}$ Nora P. Realms of memory. Rethinking the French past. P.1.

48 Åström Anna-Maria. Helsinki-muistot etnologisen historian kirjoituksen lähtökohtana // Muistin kaupunki. Tulkintoja kaupungista muistin ja muistamisen paikkana / Lento K., Olsson P. (eds.). P. 58.

${ }_{49}$ Viipurin historian kirjoitus: politiikkaa, teemoja ja aukollisuuksia. Muuttuvien tulkintojen Viipuri / Koskivirta, Paavolainen \& Supponen (eds.). Helsinki, 2016. P. 10; Cf. Karhu J. Meanings of the urban space of Vyborg for Finns.

${ }^{50}$ Nevalainen $P$. Karjala takaisin — palautuskeskustelun vaiheet sotavuosista 2000-luvulle. P. 466-468.

${ }^{51}$ Karhu J. Meanings of the urban space of Vyborg for Finns. P. 289.

52 Viiste J. Viihtyisä vanha Wiipuri: kulttuurimuistojen, kuulujen puistojen, kauniiden tornien kaupunki. Porvoo, 1945; Leppo J. Viipurilaisia . Helsinki, 1946; Berghrot K., Jääskeläinen L., Kojo V. Rakas kaupunki. Helsinki, 1951; Saivo P. Muistorikas Viipuri. Helsinki, 1953. Alone in 2010 over a hundred books dealing with the history of Vyborg were published. Cf. National Library of Finland: https://kansalliskirjasto.finna.fi/?lng=en-gb; Viipurin historian kirjoitus: politiikkaa, teemoja ja aukollisuuksia. Muuttuvien tulkintojen Viipuri / Koskivirta, Paavolainen \& Supponen (eds.). Helsinki, 2016. P. 10-12.

${ }^{53}$ Cf. Nygren H. Wiipuri: menetetty, mutta ei unohdettu urheilukaupunki A. D. 1939. Helsinki, 1986.

54 Cf. Vatanen A. Viipuri haavoittunut kaunotar. Helsinki, 2011.

${ }_{55}$ Cf. Kävelyretkiä 1930-luvun Viipurisa - Eino Partasen valokuvia / Neuvonen P. (ed.). Helsinki, 2011.

${ }_{56}$ Manninen O., Ranila K. Viipuri menetetty! Helsinki, 2014; Tarkki U. Miksi menetimme Viipurin? Helsinki, 1990.

${ }_{57}$ Cf. Manninen O., Ranila K. Viipuri menetetty!; Shikalov Y. Viipuri vapautetaan; Shika-

lov Y., Hämynen T. Viipurin kadotetut vuodet 1940-1990. Helsinki, 2013. P. 89.

${ }_{58} \mathrm{Cf}$. http://www.vsks.net/

${ }_{59}$ Cf. http://www.karjala-lehti.fi/

${ }^{60}$ For more information: Cf. web-pages of the Karelian Union: http://www.karjalanliitto.fi/ karjalan_liitto/piirit_liitot_ja_jasenseurat/pitajaseurat.

${ }^{61}$ Ilta-Sanomat special issues 14.2.2013 \& 30.5.2013.

${ }_{62}$ Cf. http://www.virtuaaliviipuri.tamk.fi/fi

${ }^{63}$ http://wiipuri.fi/ 
${ }^{64}$ Cf. Paasi A. Dancing on the graves: Independence, hot/banal nationalism and the mobilization of memory // Political Geography. 2016. Vol.54. P.21-31.

${ }_{65}$ Karhu J., Ryabova L. Meanings of the urban space of Vyborg. P. 293-294.

${ }^{66}$ Kortelainen A. Mistä puhumme kun puhumme Viipurista // Viipuri haavoittunut kaunotar / Vatanen A. (ed.) Helsinki, 2011. P. 60.

${ }^{67}$ Viipurin historian kirjoitus: politiikkaa, teemoja ja aukollisuuksia. Muuttuvien tulkintojen Viipuri / Koskivirta, Paavolainen \& Supponen (eds.). P. 10-16.

68 Åström Anna-Maria. Helsinki-muistot etnologisen historian kirjoituksen lähtökohtana // Muistin kaupunki. Tulkintoja kaupungista muistin ja muistamisen paikkana / Katri Lento \& Pia Olsson (eds.). Helsinki, 2013. P.47-48.

69 Lappi Tiina-Riitta. Kuinka mennyt merkityksellistyy kaupunkipuhunnoissa? // Muistin kaupunki, Tulkintoja kaupungista muistin ja muistamisen paikkana / Katri Lento \& Pia Olsson (eds.). Helsinki, 2013. P. 343; Karhu J. Meanings of the urban space of Vyborg for Finns.

70 The more polarised view of history can be found beneath the mainstream. Cf. Viipurin historian kirjoitus: politiikkaa, teemoja ja aukollisuuksia // Muuttuvien tulkintojen Viipuri / Koskivirta, Paavolainen \& Supponen (eds.). P. 11.

71 In survey data, the places and buildings with origins from the Soviet era are not considered important or meaningful. On average, the Russian side of Vyborg became a part of studies as late as the 21st century. Cf. Ibid.

72 Muistin kaupunki. Tulkintoja kaupungista muistin ja muistamisen paikkana / Lento K., Olsson P. (eds.). P. 19.

${ }^{73}$ Wells Ch. Vyborg: A borderland town remembered and forgotten. Master's thesis, University of Eastern Finland, Joensuu, 2014.

\title{
FOR CITATION
}

Karhu J. Memorialised and Imagined: Meanings of the Urban Space of Vyborg, Modern History of Russia, no. 3, 2017, pp. 149-162.

\begin{abstract}
In this article, I analyse both the urban space of Vyborg in relation to the Finnish tradition of memorialising the town, and the meanings given to certain places. My analysis is concentrating to three central monuments inside the city space of Vyborg: the Castle, the Round Tower and the Library. The article has its roots in our Finnish Academy project "Meanings of an Urban Space, Past and Present". Main theoretical concepts are imagined city by James Donald, places of memory by Pierre Nora and postmemory by Marianne Hirsch.

The trauma of losing Vyborg in World War II has had a great effect on the way that Finns have memorialised the town. My findings suggest that a certain tradition of memorialising (postmemory) can produce imagined and, in many ways, fixed collective views of history, which are materialising through the popular monuments of the town space. Monuments like Vyborg Castle, the Round Tower, and the Central City Alvar Aalto Library are the core places of memory for Finns. In many cases, however, they are not important because of their present reality but due to their meanings inside the imagination. These imagined realities also include strong claims of ownership towards the town space, which seems to be set in the era of Finnish independence in the 1920s and 1930s.
\end{abstract}

Keywords: Interpretations, History, Places of Memory, Postmemory, Memory, Vyborg.

Author: Karhu Jani — MA, Ph.D. Student, University of Eastern Finland (Joensuu, Finland); jani.karhu@uef.fi

References:

Alastalo M. Metodisuhdanteiden mahti: lomaketutkimus suomalaisessa sosiologiassa 1947-2000 (Tampere, 2005).

Berghrot K., Jääskeläinen L., Kojo V. Rakas kaupunki (Helsinki, 1951).

Donald J. Imagining the Modern City (London, 1999).

Harvey D. Social justice and the city (Baltimore, 1973).

Hayden D. The Power of Place (London, 1995).

Karhu J. 'Meanings of the urban space of Vyborg for Finns' in Meanings of an Urban Space. Understanding the historical layers of Vyborg, Ed. Kimmo Katajala (Zürich, 2016). 
Katajala K., Semi J. 'Meanings of an Urban Space, Past and Present' in Meanings of an Urban Space. Understanding the historical layers of Vyborg, Ed. Kimmo Katajala (Zürich, 2016).

Kervanto-Nevanlinna A. Näköaloja kadunkulmalta. Kaupunkihistorian kirjoituksia (Helsinki, 2005).

Kirby D. A Concise History of Finland (Cambridge, 2006).

Kortelainen A., Vatanen A. Mistä puhumme kun puhumme Viipurista in Viipuri, haavoittunut kaunotar, Ed. Vatanen A. (Helsinki, 2011).

Koskivirta A., Paavolainen, P., Supponen S. Viipurin historian kirjoitus: politiikkaa, teemoja ja aukollisuuksia in Muuttuvien tulkintojen Viipuri, Eds. Anu Koskivirta, Pentti Paavolainen \& Sanna Supponen (Helsinki, 2016).

Kävelyretkiä 1930-luvun Viipurisa - Eino Partasen valokuvia, Ed. Neuvonen P. (Helsinki, 2011).

Lappi T.-R. 'Kuinka mennyt merkityksellistyy kaupunkipuhunnoissa?' in Muistin kaupunki, Tulkintoja kaupungista muistin ja muistamisen paikkana, Eds. Katri Lento \& Pia Olsson (Helsinki, 2013).

Leppo J. Viipurilaisia (Helsinki, 1946).

Manninen O., Ranila K. Viipuri menetetty! (Helsinki, 2014).

Massey D. Space, Place and Gender (Minneapolis, 1994).

Memories of my town. Identities of Town Dwellers and Their Places in Three Finnish Towns, Eds. Åström Anna-Maria, Korkiakangas P., Olsson P. (Helsinki, 2004).

Muistin kaupunki. Tulkintoja kaupungista muistin ja muistamisen paikkana, Eds. Katri Lento \& Pia Olsson (Helsinki, 2013).

Nora P. Realms of memory, Rethinking the French past, vol. 1 (New York, 1996).

Nygren H. Wiipuri: menetetty, mutta ei unohdettu urheilukaupunki A. D. 1939 (Helsinki, 1986).

Paasi A. 'Dancing on the graves: Independence, hot/banal nationalism and the mobilization of memory', Political Geography, no. 54, 2016.

Petrov E., Krinitsyna T. 'From a Finnish urban space to Soviet urban planning: the Development, Approval and Implementation of the first Soviet master plan of Vyborg in 1944-1953' in Meanings of an Urban Space. Understanding the historical layers of Vyborg, Ed. Kimmo Katajala (Zürich, 2016).

Ryabova L. K. 'Meanings of the urban space of Vyborg for Russians' in Meanings of an Urban Space. Understanding the historical layers of Vyborg, Ed. Kimmo Katajala (Zürich, 2016).

Saivo P. Muistorikas Viipuri (Helsinki, 1953).

Shikalov Y. 'Russian, Lost, Fairy-tale: Images of Vyborg from the 1940s to the 2010s' in Meanings of an Urban Space. Understanding the historical layers of Vyborg, Ed. Kimmo Katajala (Zürich, 2016).

Shikalov Y. 'Viipuri vapautetaan' in Shikalov Y., Hämynen T. Viipurin kadotetut vuodet 1940-1990 (Helsinki, 2013).

Tarkki U. Miksi menetimme Viipurin? (Helsinki, 1990).

Tuomi J., Sarajärvi A. Laadullinen tutkimus ja sisällönanalyysi (Jyväskylä, 2004).

Turtola M. Viipuri ja sen linnoitukset puolustuksen symboleina in Muuttuvien tulkintojen Viipuri, Eds. Anu Koskivirta, Pentti Paavolainen \& Sanna Supponen (Helsinki, 2016)

Vatanen A. Viipuri haavoittunut kaunotar (Helsinki, 2011).

Wells Chl. Vyborg: A borderland town remembered and forgotten [Master's thesis, University of Eastern Finland] (Joensuu, 2014).

Viipurin läänin historia IV. Karjala itärajan varjossa, Eds. Kaukiainen Y., Nurmiainen J. (Porvoo, 2010).

Viiste J. Viihtyisä vanha Wiipuri: kulttuurimuistojen, kuulujen puistojen, kauniiden tornien kaupunki (Porvoo, 1945).

Åström A.-M. 'Helsinki-muistot etnologisen historian kirjoituksen lähtökohtana' in Muistin kaupunki. Tulkintoja kaupungista muistin ja muistamisen paikkana, Ed. Katri Lento \& Pia Olsson (Helsinki, 2013). 